\title{
Cross-linguistic influence of propositional and lexical semantics errors in Indonesian learner texts
}

\author{
Devina \\ Language Center, Faculty of Humanities, Bina Nusantara University, \\ 45 Kemanggisan Ilir III, Kemanggisan, Palmerah, West Jakarta, 11480
}

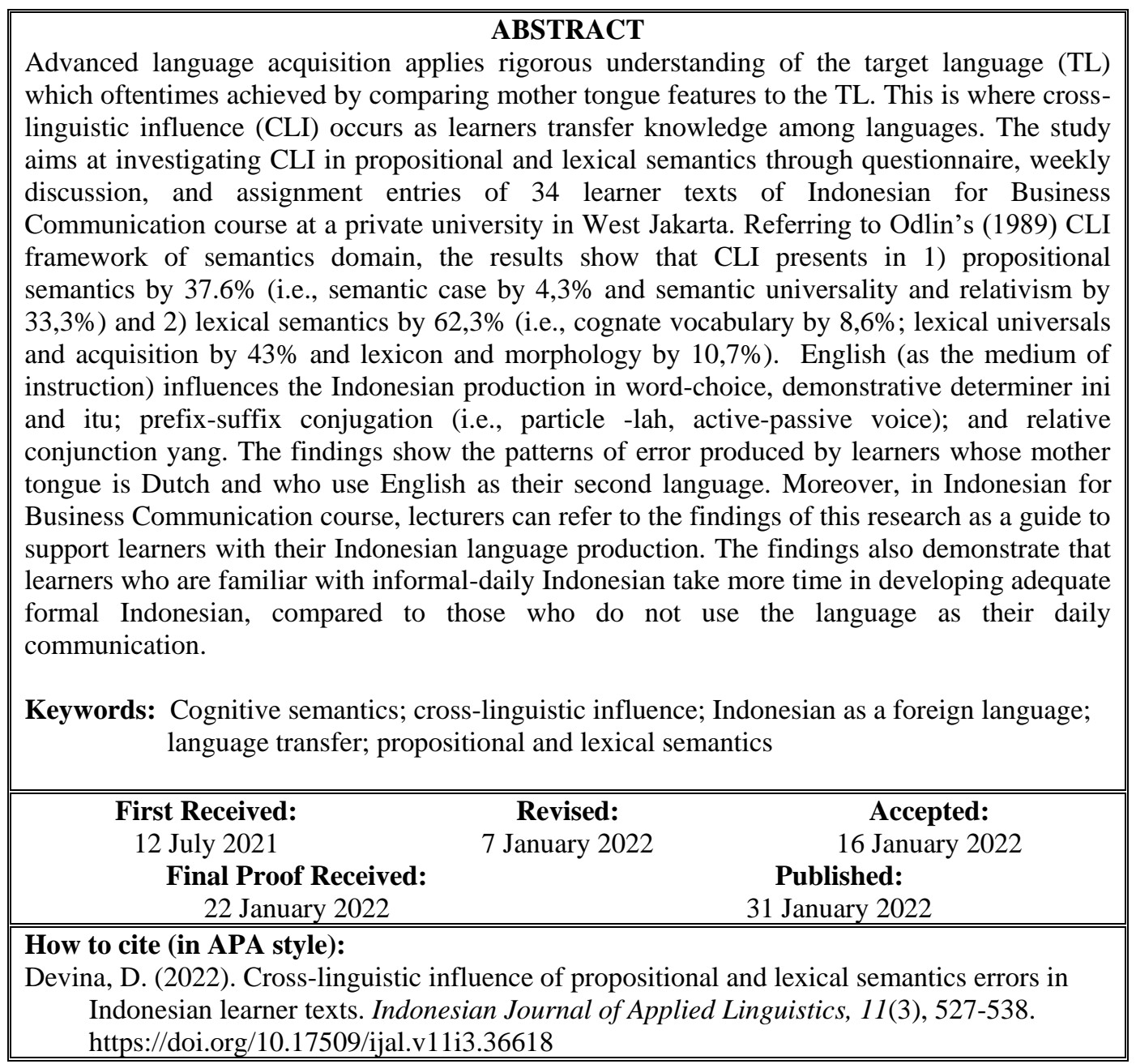

\section{INTRODUCTION}

Foreign language interest appeases a lot greater audience since being viewed as one essential factor for successful workplace recruitment. $90 \%$ of businesses agree that foreign language mastery is one competitive reason for graduates joining workforce (European Commission, 2015). Several essential workplace activities requiring foreign language mastery cover formal and informal conversation with foreign partners, listening to presentations, phone-based conversation, in-house training participation, participation in meetings, presentation, chairing a meeting (Benke, 2016), and self-efficacy beliefs (Melchor-Couto, 2018). The importance of foreign language proficiency receives support from the Organisation for Economic Cooperation and Department (OECD, 2019) to be included as one aspect of 21 st global competence (i.e., the competencies are investigating the world, recognizing perspectives, taking actions, and communicating ideas). The competence aims to allow learners and 21st citizens to enhance skills and act creatively to innovate the world (OECD, 2021). As the eminence of foreign language learning

\footnotetext{
* Corresponding Author

Email: devina005@binus.ac.id
} 
is concurrently supported by both industries and policymakers, it leads to the increasing demand for foreign language courses offered at higher education, school, and other education providers. Subsequently, this creates an expanding number of foreign language research on bilingualism and/or multilingualism.

One of the issues addressed in bilingualism and multilingualism is the influence of the mother tongue on the target language (TL). We may notice it from the World Englishes phenomenon - on how individuals bring their unique characteristics while learning English, creating variations of the target language itself (Kachru et al., 2006). A deeper look at the example is also provided by Haman et al. (2017) as the research proves that L1 production provides a significant factor to vocabulary variations and prosody production to bilingual children. Variations on L1 influence may vary from the sound production (accent), sentence formation, and meaning (semantics), to the sentence structure. Izabella (2019) suggests the influence to hinder full proficiency of the TL, while also highlighting the influence as a key factor towards TL's variations. Either way, this proves that the learner's first language (L1) brings impact to TL production. Cummins' (1989) Interdependence Hypothesis suggests that knowledge on languages constantly gives significant influence on the target language, providing that learners' motivation is high. As Kecskés and Papp (2000) put, this research discipline explores how Lx affects Ly development and Ly to Lx development accordingly for numerous purposes, such as, language acquisition and bilingualism (Zhou et al., 2020), linguistics complexity (Gao \& Ma, 2021), anxiety and selfefficacy beliefs (Bárkányi, 2021), and language fairness (Birk \& Kausel, 2016). These studies confirm that knowledge of a certain language influences on TL in various domains. Taking the term language transfer, this research field has been a topic of discussion in bilingualism for decades. However, little research is conducted with regard to variations in Indonesian language production due to the influence of another language.

At this private university located in West Jakarta, one of the foreign language courses offered is Indonesian for Business Communication. The course is open for Dutch learners as a compulsory course while undertaking an exchange program on International Business Management. The course is intended for CEFR B1 or Intermediate learners, aiming to enhance learners' business communication skills such as understanding the vocabulary, writing business reports, responding to business documents, and communicating interculturally. Having taught the course for three consecutive semesters, I could not help but notice that there have been certain unique variations of Indonesian produced by the Dutch learners. These variations are different from what native Indonesian and other foreign learners of Indonesian structured. For example, both kesenangan and kebahagiaan go for English happiness, however, there are differences in the usage. Dutch-Indonesian learners seem to use both words consecutively without realizing the differences. While not focusing on labeling what is right and wrong, this present study seeks variations of Indonesian through the learners whose mother tongue is Dutch. It is highly hoped the findings would bring and add insights to the variety of Indonesian learner texts to help lecturers understand patterns of error. To conclude, this research focuses on two questions:

(1) What are the Indonesian semantic varieties produced by the intermediate learners?

(2) To what extent do semantic varieties of CLI occur in language production?

\section{The Stance of CLI}

The issue of language transfer is also known as Cross-Linguistics Influence, henceforth called CLI. It explores the repercussion of knowledge among languages, on how the sound of L2 production is normally accentuated by prior knowledge on L1 (Odlin, 1989). For instance, the production of less stressed twirled $r$ in siempre by Spanish-English learners. This supports Müller's preposition (1998) on the research about bilingual children, as he defined language transfer as a "relief strategy" to reduce ambiguity by taking a specific knowledge from prior language system familiarity. It is hoped that the system would support an appropriate understanding of the TL.

Since holding a significant influence in Second Language Acquisition (SLA) topics for decades, views CLI has been changing along with SLA development. When behaviorism was central to SLA in the 1950s - 1960s, research on CLI assumed L1 to challenge L2 fluency (Talebi, 2014). For instance, Lado's research (1957) on comparing phonological system, syntactical structure, word choice and meaning (vocabulary), writing system, and culture stood by the idea that comparing different language systems led to reducing difficulty. This is to say that prior L1 knowledge somehow confronts TL.

In the 1970s, it has been apparent that there were two views on contrastive analysis: the strong and weak perspectives (Wardhaugh, 1970). Perspective on strong contrastive analysis holds the belief that a linguist needs to demonstrate the full knowledge of semantic, grammar, and phonology from mother tongue and TL to make the appropriate contrast between languages. The weak version, on the other hand, claimed that a linguist may conduct the analysis based on limited knowledge of the language system to spot difficulties in learning a second language. In-depth, Wardhaugh (1970) states that the strong perspective seemed to be unrealistic 
for the complexity of language system coverage before one could make any analysis on contrast, however, this was what many researchers aimed for. Subsequently, either taking on weak or strong perspective, Contrastive Analysis took the ideal that L1 or mother tongue brings difficulty in L2 learning.

Odlin (1989), in contrast, takes CLI differently as he identifies transfer between language as an awareness. Here, Odlin aimed for the benefits CLI brings to the teachers as they can address problems within students' error production and uncover error similarities among learners of diverse backgrounds.

The recent body of research on CLI has brought the issue of semantics, grammar, and phonology (Bernardini \& Grandfelt, 2019; O'brien et al., 2014) and a more complex discussion on meta-analysis and priming structure (Son, 2020; Yang et al., 2017). Yang et al. (2017) conducted a study on meta-analysis CLI review between Chinese and English on morphological, phonological, vocabulary, and decoding domains taken from 33 journal articles. Results show correlations on phonological domain to be moderate $(n=60, n=16)$; oral vocabulary domain to be small $(\mathrm{r}=.10, \mathrm{n}=15)$, decoding domain to be moderate $(r=.44, n=29)$, and morphological domain to be small $(r=.37)$. While the study does not show what CLI each domain brings nor show the similarities and differences between languages, it opens a discussion that there are common linguistic features on statistical data (correlation) between English and Chinese.

Meanwhile, Bernardini and Grandfelt (2019) investigated the linguistic complexity of syntactic structures of English, French, and Italian from learner texts. All learners' L1 is Swedish. The research specifically excels in providing analysis through computation and coding ratio in Mean Length of T-unit (MLT), Mean Length of Clause (MLC), and Subordinate Clause. Typological condition is mentioned as one factor influencing language learning. The final result indicates that null subjects are applied significantly by CEFR level A learners, while also limiting the usage of 1 st person.

Another complex discussion came from Son (2020) who explored syntactic priming structure representations between Korean and English in word order and dative structure. Priming structure occurs when learners mimic the sentence structure that they are having into their L2 production. As Korean and English differ in their respective sentence structure (English SVO and Korean SOV), the study looks at how the Korean sentence structure influence the English production. The subject of the study covers 46 English learners from beginner and intermediate levels. Participants react to several computer activities by 1 ) reading a Korean sentence 2) answering comprehension statements, and 3) completing English sentences from a picture showing the action of prompt 1 . The result indicates that English direct-object sentences are likely made after the participants read direct-object sentences (Korean). Further, English preposition-object sentence occurs accordingly after participants read PO sentence (Korea). In conclusion, priming on direct-object and preposition-object is not influenced by proficiency level. The research also notes other syntax variations; abstract representations attained from L2 higher acquisition level.

The investigation of CLI on language prosody production (rhythm, stress, and intonation) was conducted by O'brien et al. (2014) to the late learners of German and English as L2. Features of the prosody addressed are pauses/second, speech rate, filled pauses, word repetition, and mean length run. The experiment involved 32 late learners who were asked to read aloud German and English texts (16 German L2 learners and 16 English L2 learners), which being analyzed through Praat. The study proves that learners disambiguate prosodic language production. For L2 German learners, the prosodic language production occurs and takes F0 on pitch accent and direct-object on mit preposition to disambiguate noun-phrase attachment. Further, the prosodic language production of L2 English learners occurs for the word with to disambiguate verb-phrase attachment. The study highlighted the capability of German and English learners to produce adequate prosodic sound to disambiguate their language production from the same language feature (i.e., preposition), although being considered as a late learner.

\section{Semantic Domain in CLI}

Semantics involves the study of meaning, including word, phrase and sentence (Yule, 2020). Having learner texts as the main source for the data, this research focuses on the semantic domain in CLI.

In CLI semantical analysis, Odlin (1989) divided the domain into propositional and lexical semantics. Propositional semantics looks at the logical truth in a sentence. In SLA, it analyzes what language brings to thought or understanding the meaning of a statement. The tenet also looks at what lies between the logic and culture of the target language. One issue that propositional semantics addresses is how far semantical structure in mother tongue influences L2 thinking process. For example, the production of either passive or active sentence allows researcher to highlight the entities that speaker draws from their mother tongue. A deeper look at propositional semantics presents the reader with semantic case (e.g., the tendency of using active or passive forms), and morphological case (e.g., suffix and prefix).

Odlin (1989) also came up with lexical semantics that deals with how learners transfer knowledge on L1 to vocabulary in L2. For example, the English word excellent is excelente in Spanish. 
Noting some similarities of vocabulary aids learners to focus on other unfamiliar words (Solman \& Chung, 1996). However, word similarity in different languages does not always refer to the same thing, for example, sugesti in Indonesian does not hold the same meaning as suggestion in English. Learners need to be careful as not all similar words stand for the same meaning, especially if a local context plays part. This word similarity is known as cognate by Odlin. A further discussion of lexical semantics brings us to linguistic relativism, which is the stance for how learners grasp the idea of foreign words. Such errors in Indonesian-English L2 learners can be viewed from the phrase I'm not patient for the package to come to what it truly means (i.e., I'm could not wait for the package to come). The adjective sabar stands for being patient and could not wait. Indonesian-English learners often use the word interchangeably, when it is not. Lastly, the relationship between lexical meaning and morphology (i.e., lexicon and morphology) is also a part of the lexical semantics looking at affixes (prefix and suffix) between the transfer. It may support, as well as constraint L2 comprehension.

All in all, Odlin's exploration on semantics domain in CLI notes several semantical attributes. In propositional semantics, there are (1) semantic universality and relativism (meaning and thought), (2) semantic case (syntactic structure that changes the meaning). For lexical semantics, Odlin delved into (1) cognate vocabulary (similar vocabulary), (2) lexical universals and acquisition (the interception of new words), and (3) lexicon and morphology (morphological attributes that either help or undermine comprehension).

\section{METHOD}

Respondents

All participants are intermediate learners of Indonesian (CEFR B1) who take an exchange program, majoring in International Business Management (streaming Southeast Asian studies). The original course is designed to strengthen learners' business Indonesian because an internship in Indonesia needs to be conducted in the following semester. However, reacting to the COVID-19 health crisis, the current program runs online. The participants are between $22-27$ years old. Through the survey, they all have the same motivation that is to strengthen and enrich their Indonesian for business communication. All participants have taken Indonesian courses in their home university in the Netherlands; however, it is not specifically designed for business communication. Yet, a strong foundation of Indonesian has been achieved and most learners can produce Indonesian well for daily and/or informal contexts. However, difficulties in producing formal language are apparent throughout the session. It is worth noting as well that 3 participants have Indonesian descents and use the language for simple and daily communication with their family members, hence these learners use the target language more actively than the rest. When needed, English is used as the language of instruction.

\section{Instruments and Procedures}

Both qualitative and quantitative strategies are used for data collection. The main data (quantitative) were obtained from weekly assignments. In total, there are 34 entries of learners' texts of Indonesian for Business Communication course in one single semester. The texts are a set of writing productions from weekly assignment entries, submitted by 6 students.

Additionally, a questionnaire was distributed at the beginning of the course. The questionnaire asks about their age, previous experience of learning Indonesian, and their motivation for joining the course. The details help the study to relate why a particular language use, expression, or vocabulary is used. Through the questionnaire, it is also known that 3 learners are having Indonesian descendants and use Indonesian for daily communication with their family members.

Apart from that, classroom recording of weekly discussions made an important contribution as well. In this step, the teacher delves more into the reasons and considerations that learners take while making the error. Reflection is one important step here so that it is known the fundamental issue learners took while learning. In then, this sets clear distinction on which error is purely made by learners' understanding and that of CLI.

\section{Data Analysis}

The quantitative data (i.e., assignment entries) were then analyzed by noting the errors made by the students. It was decided that the best analysis done to the students' assignment entry is through Error Analysis, by noting the less suitable use of Indonesian. Error Analysis approach was selected to tell which part students need to improve their language production, and at the same time, to reveal varieties of Indonesian produced by learners. Odlin's (1989) component for semantics domain in CLI was carefully chosen as the analysis framework. Firstly, the analysis of sentence or language expression that contains error was conducted. Only errors in semantics were being explored in this study. Then, the errors were labeled into several categories based on Odlin's (1989) semantic framework It is worth noting that both lexical and prepositional semantic overlap in some longer text. For sentences that contain multiple errors, each error was counted. The following Figure 1 is an example. 
Figure 1

Example of Multiple Error Analysis in a Single Sentence

Terdapat $\underline{\text { meningkat }}$ pada angka pertimbuhan penduduk Indonesia $\left[^{\wedge}\right]$ drastic.

(1)

Five errors exist in the above statement related to noun conjugations (1 and 2), relative clause (3), cognate vocabulary (4), and word structure (4). Errors in number 1 and 2 with lexical semantics; number 3 deals with propositional semantics; number 4 deals with cognate vocabulary and word structure. This study will not present all errors, but rather provide examples of how each component in semantic CLI exists and what transfer makes such errors. All errors are labeled and converted into percentage.

Data from the questionnaire provide information related to the learner regarding their age, reason of enrollment, and prior Indonesian Figure 2

Research Roadmap

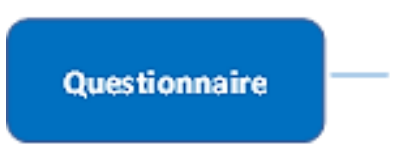

Learner's background: age, experience of learning Indonesian, motivation, family of Indonesian descendants
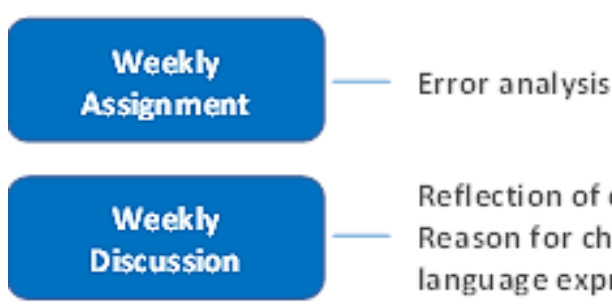

Reflection of error,

Reason for choosing certain language expression

\section{FINDINGS AND DISCUSSION}

\section{Learners Overview}

All participants who enroll in the Indonesian for Business Communication course have prior knowledge of A1-A2 Indonesian from their home university. Having the same motivation to enhance learning experience and family background. The second data analysis was conducted on 34 weekly assignment entries. The entries confirmed that errors did occur. Types of error were also identified and labeled into semantics domain. Weekly assignment analysis went concurrently with weekly discussion. Learners had 1 week time to finish their weekly task, then the task was graded. Learners' performance in the task was then discussed in the following session. The discussion highlights their mistake, reviews their performance, and find the reason why such language variation is chosen. The following diagram in figure 2 is to depict the research roadmap.

Table 1

Learners' Overview

\begin{tabular}{ccccc}
\hline No & Learners & Age & Reason for studying Indonesian & $\begin{array}{c}\text { Have family or distant family, } \\
\text { and use Indonesian for daily } \\
\text { communication }\end{array}$ \\
\hline 1 & Learner 1 & 22 & $\begin{array}{c}\text { Acquire Indonesian as a second } \\
\text { language and academic purposes }\end{array}$ & Yes \\
2 & Learner 2 & 25 & Work and academic purposes & Yes \\
3 & Learner 3 & 23 & Academic purposes & No \\
4 & Learner 4 & 23 & Casual leisure and work purposes & Yes \\
5 & Learner 5 & 26 & Academic purposes & No \\
6 & Learner 6 & 27 & Acquire Indonesian as a second & No \\
\hline
\end{tabular}


Regarding CLI, Learner 1, Learner 2, and Learner 4 produce more informal language than Learner 3, Learner 5, and Learner 6. This happens because learners who are using Indonesian with their family or distant family members are exposed more to informal Indonesian. Respectively for these learners (Learner 1, 2 and 4), they take more time in getting used formal Indonesian business. Having used the Indonesian for daily communication, the learners are having difficulty to adjust to formal language use. Apart from that, when corrections are given Learners 1, 2, and 4, do not immediately apply the correction and make the same error. This is different with Learner 3, 5, and 6 who apply the correction directly. It is worth to note that formal and informal (daily) Indonesian are highly different. The result indicates that at B1 level, when learners are exposed highly to informal Indonesian, they will take more time and effort to adapt to formal Indonesian use compared to those who infrequently use it.

\section{Indonesian Semantic Varieties by the Intermediate Learners \\ Of 34 weekly assignment entries, it is confirmed that a number of 93 errors take place. Significantly, propositional semantics occurs for $37,6 \%$ (i.e., semantic case is $4,3 \%$ and semantic universality and relativism is $33,3 \%$ ) and lexical semantics occurs for $62,3 \%$ with the distributions of; cognate vocabulary for $8,6 \%$; lexical universals and acquisition for $43 \%$; and lexicon and morphology for $10,7 \%$. The graphs are in Figure 3 as follows.}

\section{Figure 3}

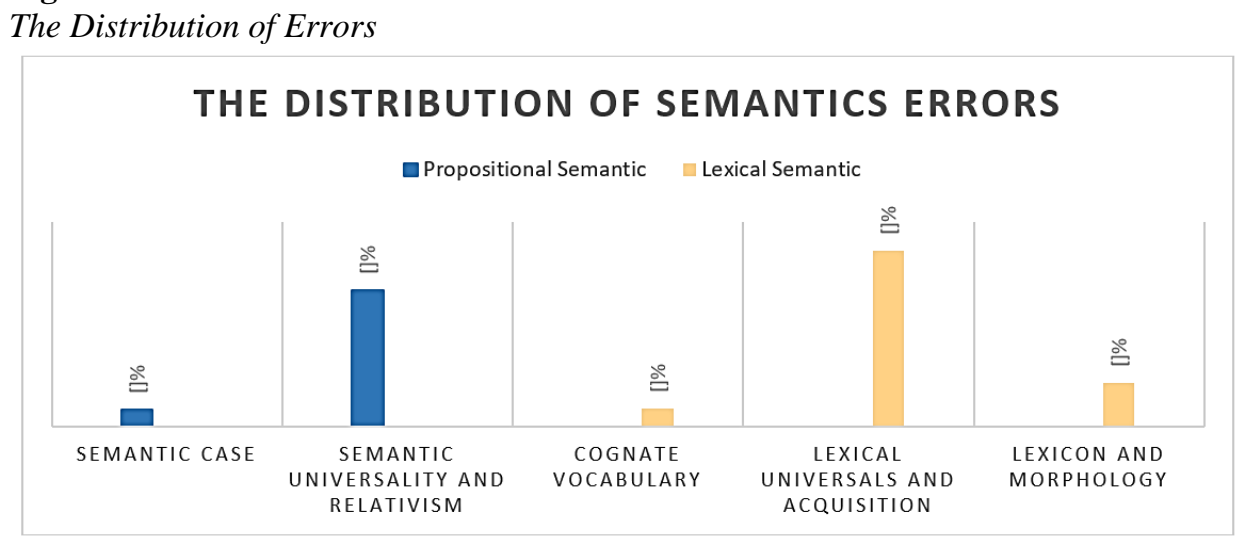

\section{Propositional Semantics}

The observation of propositional semantics looks at the relationship between statement and meaning. The error analysis of semantic case reveals that learners are having difficulties in using relative conjunction yang (ID) / that is (EN) when combining clauses. The following Table 2 presents the examples.

Table 2

Example of CLI in Semantic Case Within Relative Conjunction 'Yang'

\begin{tabular}{cll}
\hline & Learner Texts with Error & Revised Statement \\
\hline ID & $\begin{array}{l}\text { Percakapan yang kolaboratif adalah dapat } \\
\text { membangun hubungan. }\end{array}$ & $\begin{array}{l}\text { Percakapan yang kolaboratif adalah percakapan yang } \\
\text { dapat membangun hubungan. }\end{array}$ \\
EN & $\begin{array}{l}\text { A conversation that is collaborative is may build } \\
\text { relationship. }\end{array}$ & $\begin{array}{l}\text { Conversation that is collaborative is the conversation that } \\
\text { may build relationship. }\end{array}$ \\
\hline
\end{tabular}

The error seen in the above statement depicts that the use of relative conjunction yang has not been fully acquired. There are two cases of the use of yang in this sense (1) yang to combine adjective and noun, and (2) yang as relative conjunction. The following figure (figure 4) explains the errors in the sentence.

\section{Figure 4}

Explanation of Errors in Semantic Case

\section{Percakapan yang kolaboratif adalah percakapan yang dapat membangun hubungan.}

$$
\text { (yang for Adj+Noun) (yang for Relative Clause) }
$$

EN: Conversation that is collaborative is the conversation that may build relationship.

$\mathrm{EN}$ : Collaborative conversation is the conversation that may build relationship. 
Firstly, yang is used to combine adjectives and nouns. The sentence conversation that is collaborative is the Indonesian way of saying collaborative conversation. Additionally, yang is the relative clause for who, which, whom, whose, and that. In English, there is a condition where a reduced relative clause takes place, for example, the sentence the doctor whom my mother adores is brilliant is the same as the doctor my mother adores is brilliant. Indonesian relative clause of yang does not occur the same. There is no condition for reduced or omit yang relative clause. From this condition, CLI in semantic case reveals that the use of yang is not yet fully acquired in the condition when more than one function is used. Further, having two relative clauses yang at the same time leads learners to neglect the subject from the second clause as well (i.e., percakapan).

One discussion topic in Indonesian for Business Communication is reading and making infographics. The grammatical feature from the chapter is particle -lah. The other usage of the particle -lah (i.e., to soften command, to firm declarative sentence) has commonly been acquired. The example can be seen in table 3 as follows.

Table 3

Example of CLI in Semantic Case Within Particle -Lah

\begin{tabular}{lll}
\hline & Learner Texts with Error & Revised Statement \\
\hline ID & $\begin{array}{l}\text { Sangat sopan untuk berterima kasih kepada orang lain } \\
\text { sebelum dan sesudah wawancara. }\end{array}$ & $\begin{array}{l}\text { Sangatlah sopan untuk berterima kasih kepada orang lain } \\
\text { sebelum dan sesudah wawancara. }\end{array}$ \\
EN & $\begin{array}{l}\text { Saying thank you to other people before and after interview is very polite // } \\
\text { It is very polite to say thank you to other people before and after interview. }\end{array}$ \\
\hline
\end{tabular}

Particle -lah is also known as predicative marker (Sneddon, 1996), which occurs when the predicate is located before the subject. Here, the predicate, sangat sopan (EN: very polite), is located at the beginning of the sentence, so it needs particle -lah. This type of sentence applies some degree of complexity since the predicate needs to be structured at the beginning of the sentence, changing the overall sentence structure. In English, the closest translation of the sentence would be It is very polite to say thank you other people before and after interview. It is apparent that English has almost the same sentence structure, but not with stressing particle. For having the same structure, it is easier for learner to make the same pattern, however, since
English does not apply any particle, this influences the production of Indonesian. Learner thinks that changes in the predicate are not needed, when it should. The language transfer of English and Indonesian brings forth the variation of inverted sentence. Semantically, when particle -lah is used with a predicate at the beginning of the sentence, the meaning of the sentence contains firmness.

The second propositional semantics is semantic universality and relativism which occurs for $33.3 \%$ of the study. Semantic universality and relativism deal with the process of thinking and how language production is very much inspired by other languages. The example is as seen in table 4.

Table 4

Example of CLI in Semantic Universality and Relativism Within the Demonstrative Pronoun Ini

\begin{tabular}{lll}
\hline & Learner Texts with Error & Revised Statement \\
\hline ID & Dia melakukan ini dengan mencari kemitraan & Dia melakukan hal ini dengan mencari kemitraan untuk \\
& untuk mempercepat proses proyek. & mempercepat proses proyek. \\
EN & He does this (thing) by acquiring partnership to accelerate the progress of project.
\end{tabular}

Ini (EN: this) is demonstrative determiner to refer to something or someone close (this) or far (that) from the object. In this example, CLI examines the use of demonstrative determiners with prior discussion on a certain subject matter. In the sentence, He does this by acquiring..., reader knows that this refers to something being discussed previously. Unlike English, the Indonesian sentence of this type of demonstrative determiner will need another general noun to accompany this. Such nouns are thing (i.e., EN: this thing, ID: hal ini), circumstance (i.e., EN: this circumstance, ID: keadaan ini), and condition (i.e., EN: this condition, ID: kondisi ini). The appropriate sentence in
Indonesian would be Dia melakukan hal ini..., however, most of the time the general noun is neglected. The language knowledge that learner takes from English, clearly influences the production of adding general noun in Indonesian demonstrative determiner. In addition, this also happens to itu (EN: that) demonstrative determiner. Likewise, the sentence $\mathrm{Hal}$ itu adalah alasan mengapa pemerintah... (EN: That is the reason why the government...) is frequently written as Itu adalah alasan mengapa pemerintah..., neglecting hal for such structure does not exist in English.

Lexical Semantics 
The lexical semantics that occurs in this study covers $62.3 \%$ with the following distributions: cognate vocabulary for $8.6 \%$, lexical universals and acquisition for $43 \%$, and lexicon and morphology for $10.7 \%$.

Cognate vocabulary proposes the key concept that similar words from Lx with target language could support acquisition. The idea is that learners could focus on other words, that are not similar with the Lx (Odlin, 1989). However, in this research, several cognate vocabularies in Indonesian contain mistakes influenced by English vocabularies. The list of words is in the following Table 5.

Table 5

\begin{tabular}{cll}
\multicolumn{2}{c}{ List of CLI in Cognate Vocabulary } & \\
\hline No & Learner Texts with Error & Revised Vocabulary \\
\hline 1 & $\begin{array}{l}\text { Dia mulai bekerja di Gojek pada } 2015 \text { sebagai president. } \\
\end{array}$ & $\begin{array}{l}\text { EN: He started working in Gojek in } 2015 \text { as president. } \\
\text { Terdapat meningkat angka pertimbuhan penduduk Indonesia drastic. }\end{array}$ \\
& $\begin{array}{l}\text { EN: There is a drastic increase in Indonesian population growth } \\
\text { Saya merekomdasi tempat ini untuk teman-teman... }\end{array}$ & ID: drastis \\
4 & $\begin{array}{l}\text { EN: I recommend this place to friends... } \\
\text { Grafiek ini tentang konsumsi Mie Instan di Indonesia. }\end{array}$ & ID: \\
& $\begin{array}{l}\text { EN: This graphics is about Instant Noodle consumption in Indonesia } \\
\text { Banyaknya konsumsi per tahun menimbulkan... } \\
\text { EN: The amount of consumption per year causes... }\end{array}$ & ID: grafik \\
\end{tabular}

The second domain of lexical semantics is lexical universals and acquisition, which refers to the target language's choice of words or phrases influenced by Lx. In other words, it deals with how learners perceive and use the language - that has been impacted by their prior knowledge. Lexical universals and acquisitions hold the most occurrence in this research, by $43 \%$. There are two types of

Table 6

Example of CLI in Lexical Universals and Acquisition

\begin{tabular}{|c|c|c|c|}
\hline No & Learner Texts with Error & $\begin{array}{l}\text { Revised } \\
\text { Vocabulary/Phrase }\end{array}$ & $\begin{array}{l}\text { Types of } \\
\text { Acquisition }\end{array}$ \\
\hline 1 & $\begin{array}{l}\text { Penjualan Xiaomi menurun di awal } 2019 \text { dan kemudian } \\
\text { tumbuh lagi... } \\
\text { EN: Xiaomi's sales decreased in the beginning of } 2019 \text { and } \\
\text { then increased again... }\end{array}$ & ID: meningkat & $\begin{array}{l}\text { Word choice with } \\
\text { multiple definitions }\end{array}$ \\
\hline 2 & $\begin{array}{l}\text { Dan kalau anda mau bersantai dan mau udara segar, anda } \\
\text { bisa pergi ke balkon untuk hidung segar. } \\
\text { EN: And if you would like to relax and get some fresh air, } \\
\text { you can go to the balcony to get fresh air. }\end{array}$ & $\begin{array}{l}\text { ID: Untuk mendapatkan } \\
\text { udara segar }\end{array}$ & $\begin{array}{l}\text { Word choice with } \\
\text { multiple definitions }\end{array}$ \\
\hline 3 & $\begin{array}{l}\text {..harga pangan bergelombang selama } 9 \text { bulan terakhir. } \\
\text { EN: ... the price of food has been fluctuating for the last } 9 \\
\text { months. }\end{array}$ & ID: fluktuatif & $\begin{array}{l}\text { Word choice with } \\
\text { multiple definitions }\end{array}$ \\
\hline 4 & $\begin{array}{l}\text { Terdapat jatuh yang bermakna pada jumlah calon } \\
\text { mahasiswa. } \\
\text { EN: There is a meaningful decrease in the number of } \\
\text { prospective students. }\end{array}$ & $\begin{array}{l}\text { ID: penurunan yang drastis, } \\
\text { penurunan yang signifikan }\end{array}$ & $\begin{array}{l}\text { Lexical meaning } \\
\text { within cognate } \\
\text { vocabulary }\end{array}$ \\
\hline 5 & $\begin{array}{l}\text {...produk kami akan meringankan sakit punggung Anda } \\
\text { dengan mengoreksi postur Anda sepanjang hari. } \\
\text { EN: ...our product will relieve your back by correcting } \\
\text { your posture throughout the day. }\end{array}$ & ID: memperbaiki & $\begin{array}{l}\text { Lexical meaning } \\
\text { within cognate } \\
\text { vocabulary }\end{array}$ \\
\hline
\end{tabular}

Table 6 shows that learners use the verb tumbuh (EN: grow) to indicate increase in the sales in the first example. The second example presents the phrase untuk hidung segar (EN: for a fresh nose) to refer to get a fresh air. While aiming for the word air, the learner takes nose instead, making the meaning is not right. Apart from that, the learner does not put the verb get, while it is needed. influence in the acquisition that learners made; (1) CLI in words that contain multiple meanings, and (2) CLI in lexical meaning within cognate vocabulary. For the first type, such vocabulary and/or phrases learners use are direct translation from English. The examples are in the following Table 6 .
Additionally, example 3 shows how the word bergelombang (EN: waving) used to refer to fluctuate. While the words choice shares almost the same meaning, waving is not quite right to explain something related to the number of students' enrollments. A more comprehensive example can be seen from example 4, jatuh yang bermakna (EN: meaningful fall). What the learner means is drastic 
drop (penurunan yang drastis). In this sense, the learner uses words in the same semantics field containing related meanings. However, it is not the direct synonym and making the use of it less suitable. Native speaker of Indonesian will take penurunan (EN: decrease), instead of kejatuhan (EN: drop), and take drastis (EN: drastic) instead of bermakna. Example 5 presents us with a case when acknowledging cognate vocabulary (ID: mengoreksi, EN: correcting) leads to making assumption that the word correcting could be used the same as in English. Yet, when this does not happen, the right statement is not achieved.

The last lexical semantics in this research concerns with lexicon and morphology. This research provides language transfer within prefix and suffix in verb conjugation and passive-active statement. The transfer occurs for the following data as presented in table 7 below.

Table 7

Example of CLI in Lexicon and Morphology

\begin{tabular}{|c|c|c|c|}
\hline No & Learner Texts with Error & $\begin{array}{l}\text { Revised } \\
\text { Vocabulary }\end{array}$ & $\begin{array}{l}\text { Types of } \\
\text { Lexicon }\end{array}$ \\
\hline 1 & $\begin{array}{l}\text { Sampai tahun 2015, jumlah orang yang kuliah konsisten. } \\
\text { EN: Until } 2015 \text {, the number of people studying to college was consistent. }\end{array}$ & ID: berkuliah & Prefix ber- \\
\hline 2 & $\begin{array}{l}\text { Produk ini unisex dan sangat nyaman dipakai dan mudah untuk } \\
\text { menyesuaikan. } \\
\text { EN: This product is unisex and very comfortable to be used and easy to be } \\
\text { adjusted. }\end{array}$ & ID: disesuaikan & $\begin{array}{l}\text { Prefix me- } \\
\text { and suffix - } \\
\text { kan }\end{array}$ \\
\hline
\end{tabular}

Example 1 in table 7 is about using prefix berto Example 1 in table 7 is about using prefix ber- to make the verb. When prefix ber- combines with noun, it makes the noun change into verb. The first example shares how prefix ber- is not used in the sentence, making the structure is not right. Next, the error in example 2 addresses the use of prefix to indicate active and passive statement. Prefix meindicates active verb, while prefix di- refers to passive verb. Two verbs in example 2 are indicated; dipakai (EN: to be used); menyesuaikan (EN: to adjust). The sentence contains passive voice, and the learner has provided the right verb conjugation within the first clause (i.e., dipakai - passive), however, when another clause is added, the learner uses active verb conjugation (i.e., menyesuaikan active) making the sentence error. What makes the learner use active verb is shown in the following figure 5 .

\section{Figure 5}

Explanation of CLI in Verb Conjugation within Passive-active Voice

Produk ini unisex dan sangat nyaman dipakai dan mudah untuk menyesuaikan.

This product is unisex and very comfortable to be used and easy to be adjusted

The use of untuk (EN: to) is what makes the learner putting the active verb conjugation as normally to in English is followed by active voice.

\section{The Semantic Varieties of CLI in Language Production}

This section discusses the extent to which semantic varieties of CLI occur in learners' language production. In this present study, it refers to the fundamental of English in Indonesian production.
As the learners are in their intermediate (CEFR B1) level, using Indonesian is fully encouraged. However, some learners are having difficulty to understand long instruction and comprehensive explanation. Hence, when it is necessary, English is used to give instruction, as well as giving explanation. In some more technical discussion (e.g., explaining grammatical features), English is not only used to explain, but also to give illustration and comparison with Indonesian features. Through the following paragraphs, the study proves that illustration made to English significantly contributes to Indonesian production. The discussion reports on how English takes part in each domain of semantics.

The highest CLI in this study is lexical universals and acquisition of lexical semantics $(43 \%)$, addressing the learners' choice of words or phrases. Influences on error are found out on the words with more than one meaning and the vocabulary of cognate. With this type of usage, learners do not normally aware of the meaning of their word choice. Having looked the definition in the dictionary and using the features of thesaurus make them believe that their choice of vocabulary is interchangeable. For example, the learners use tumbuh (EN: grow) to indicate meningkat (EN: increase). The second type overlaps a little with cognate vocabulary, however, in this part, cognate words influence the word choice. Through weekly synchronous session, it is acknowledged that the learners are not aware that their choice of words is not correct. The learner takes mengoreksi (EN: correct) to be used in memperbaiki (EN: improve). In English, according to Merriam-Webster online dictionary, the two words are considered as related words. However, it is not the case in Indonesian texts as the words are not used interchangeably.

Semantic universality and relativism (propositional semantics), which holds the second- 
highest percentage of CLI $(33,3 \%)$, deals with the process of thinking and production of the language. This research reveals the use of demonstrative determiner ini (EN: this) and itu (EN: that). Compared to Indonesian, it is alright in English to say This proves that the method works. The use of this in the sentence does not need other general nouns. In Indonesian, however, it happens the opposite, it requires additional general noun. Hence, the suitable Indonesian texts to the above example would be Hal ini membuktikan bahwa metode tersebut berhasil. Note that there is an additional noun hal (EN: things) that is needed before the determiner. This case of demonstrative determiner is one of the challenging topics in the course. Learners admit that acknowledging and being consistent to always put general and abstract nouns before the determiner is strange, as usually, they do not. This research also notes several general and abstract nouns in Indonesia for this case which are hal (EN: things), kondisi (EN: condition), and keadaan (EN: circumstance).

Next, lexicon and morphology of lexical semantics $(10,7 \%)$ looks at the influence prefixsuffix conjugation and passive-active sentence. Unlike those in English, Indonesian word conjugation occurs differently. Conjugation in Indonesian happens to the verb, noun, and adjective, by putting the prefix and/or suffix. When both prefix and suffix are combined, errors are more frequent to happen. The research reveals that learners have understood the concept of most conjugation and are able to apply it in simple terms. Either through direct response or weekly assignment, learners are able to show this skill in simple sentences. Regardless, in longer sentence, or sentence that starts with prepositional phrase, mistake in conjugation is apparent. As learners are trying to bounce information back and forth between languages, they put the focus a lot on structuring the sentence and forgetting the features of conjugation. Subsequently, when asked directly in synchronous sessions about their error, learners can easily address and revise their mistake at once. This shows that understanding on producing words with conjugation does exist, however, complex sentence production hinders it.

Cognate vocabulary of lexical semantics $(4,6 \%)$ is important in enriching similar vocabulary. Consequent with Odlin's (1989) research, this study also finds cognate to both support and confuse learners. Several errors in cognate happens as learners take the English vocabularies (e.g., president, drastic) or mistakenly changing the word (e.g., konsumsu instead of konsumsi, merekomdasi instead of merekomendasikan, grafiek instead of grafik). Specifically with the case of merekomendasikan, learners find it difficult because the word contains cognate (i.e., rekomendasi) and prefix-suffix conjugation (i.e., prefix $m e$ - and suffix $-k a n)$.

The last semantic component is semantic case from propositional semantics $(4,6 \%)$. It looks at the semantic role, the meanings that a sentence conveys. The study reveals that semantic case occurs in Indonesian adjective and relative clause, within the use of yang. It is frequent to elaborate adjectives in the sentence percakapan yang kolaboratif (EN: a conversation that is collaborative), even when there is no relative clause. Yang also works with relative clause, for example percakapan yang dapat membangun hubungan (EN: conversation that may build relationship). With this double usage of yang in a sentence, learners do not produce the second yang because it is odd to use two relative conjunctions. As in English, normally relative conjunction is used to combine two clauses.

From the questionnaire, it is also known that three learners were born in Indonesian family who live in the Netherlands. These learners actively use Indonesian for daily communication with their family members. For these 3 learners, formal Indonesian acquisition takes a longer time than the rest. This happens because application of the informal language being used consistently hindering the formal language use. Therefore, the study confirms what Lado (1957) brought into discussion, that CLI could strengthen and weaken language acquisition.

The findings confirm the work of Yang et al. (2017), Son (2020), Bernardini and Grandfelt (2019), and O'brien et al. (2014) which discover that past knowledge of any language affects the TL. As the existing research explored morphological, phonological, vocabulary and decoding domain meta-analysis (Yang et al., 2017); direct-object proposition of English with the influence of Korean (Son, 2020); computation data on semantic, grammar, and phonology between English and Chinese (Bernardini \& Grandfelt, 2019); and prosody production between German and English (O'brien et al., 2014), the findings of this present study add more insights in semantic domain exploration. The exploration particularly provides thorough examples for each component (i.e., semantic case; semantic universality and relativism; cognate vocabulary; lexical universals and acquisition; and lexicon and morphology) from Indonesian texts.

\section{CONCLUSION}

The study focuses on investigating semantic components of CLI in Indonesian as a foreign language course. Using Odlin's (1989) framework of semantic domains, it confirms that mostly, CLI occurs in lexical universals and acquisition (43\%). Then, they are followed by semantic universality and relativism $(33.3 \%)$, lexicon and morphology 
(10.7\%), cognate vocabulary $(8.6 \%)$, and semantic case $(4.3 \%)$. The above data and cases show that learners tend to compare Indonesian to English usage in terms of vocabulary and sentence structure. To make sure learners' comprehension is achieved, oftentimes, English is used as a medium of instruction to explain technical materials (e.g., sentence structure). This occurs especially when learners are facing difficulty while understanding complex material, such as long sentences, reduced clauses, special exceptions in affixes, etc. Therefore, comparison of the two languages is inevitable. This comparison also becomes the major influence in Indonesian production since learners rely on the structure of English while trying to understand Indonesian language features. This research highlights the patterns of semantic problems. Noting the pattern supports teachers when teaching the course, as they may draw on the patterns to highlight any troublesome topic. Further research in CLI may discuss other domains, such as discourse and prosody, as well as designing the material based on the patterns of error.

\section{REFERENCES}

Bárkányi, Z. (2021). Motivation, self-efficacy beliefs, and speaking anxiety in language MOOCs. ReCALL, 33(2), 143160. https://doi.org/10.1017/s0958344021000 033

Benke, E. (2016). Foreign language needs in the workplace: The occupational perspective. Some Issues in Pedagogy and Methodology, 98-107. https://doi.org/10.18427/iri-2016-0070

Birk, S. J., \& Kausel, E. E. (2016). The language of fairness: How cross-linguistic norms in Spanish and English influence reactions to unfair treatment. The Spanish Journal of Psychology, 19, 115. https://doi.org/10.1017/sjp.2016.81

Bernardini, P., \& Granfeldt, J. (2019). On cross-linguistic variation and measures of linguistic complexity in learner texts: Italian, French and English. International Journal of Applied Linguistics. 29(2), 211-232. https://doi.org/10.1111/ijal.12257

Cummins, J. (1989). Linguistic interdependence and the educational development of bilingual children. Review of Educational Research, 49(2), 222-251. https://doi.org/10.3102/00346543049002222

European Commission. (2015). Study on foreign language proficiency and employability: Final report. https://www.erasmusplus.sk/kniznica/publika cie/Final_Report.pdf

Gao, J., \& Ma, S. (2021). Learning condition, linguistic complexity, and first language transfer in semiartificial language learning. Studies in Second Language Acquisition, 43(2), 355378. https://doi.org/10.1017/s0272263120000 686

Haman, E., Wodniecka, Z., Marecka, M., Szewczyk, J., Białecka-Pikul, M., Otwinowska, A., \& Foryś-Nogala, M. (2017). How does L1 and L2 exposure impact L1 performance in bilingual children? Evidence from Polish-English migrants to the United Kingdom. Frontiers in Psychology, 8, 1-21. https://doi.org/10.3389/fpsyg.2017.01444

Izabella, R. (2019). Cross-linguistic influence - A friend or a foe. ERD 2018 6th International Conference - "Education, Reflection, Development, Sixth Edition,” (pp. 203-210). https://doi.org/10.15405/epsbs.2019.06.26

Kachru, B., Kachru, Y., \& Nelson, C. (2006). The handbook of world Englishes. Blackwell Publishing.

Kecskés, I., \& Papp, T. N. (2000). Foreign language and mother tongue (1st ed.). https://doi.org/10.4324/9781410606464

Lado, R. (1957). Linguistics across cultures: Applied linguistics for language teachers. University of Michigan Press.

Melchor-Couto, S. (2018). Virtual world anonymity and foreign language oral interaction. $\operatorname{ReCALL}, 30(2), 232-$ 249. https://doi.org/10.1017/s0958344017000 398

Müller, N. (1998). Transfer in bilingual language acquisition. Bilingualism: Language and Cognition, 1(3), 151-191.

O'brien, M. G., Jackson, C. N., \& Gardner, C. E. (2014). Cross-linguistic differences in prosodic cues to syntactic disambiguation in German and English. Applied Psycholinguistics, 35(2014), 27-70. https://doi.org/10.1017/S0142716412000252

Odlin, T. (1989). Language transfer: Crosslinguistic influence in language learning. Cambridge University Press. https://doi.org/10.1017/CBO9781139524537

OECD. (2019). PISA 2018 assessment and analytical framework. https://doi.org/10.1787/b25efab8-en

OECD. (2021). PISA 2025 foreign language assessment framework. https://www.oecd.org/pisa/foreignlanguage/PISA-2025-FLA-Framework.pdf

Sneddon, J. N. (1996). Indonesian: A comprehensive grammar. Routledge.

Solman, R. T., \& Chung, K. K. (1996). Language transfer and blocking in second language vocabulary learning. Journal of Behavioral Education, 6(2), 173-190. https://doi.org/10.1007/bf02110231 
Son, M. (2020). Cross-linguistic syntactic priming in Korean learners of English. Applied Psycholinguistics, 41(5), 1223-1247. https://doi.org/10.1017/s0142716420000545

Talebi, S. H. (2014). Cross-linguistic transfer among Iranian learners of English as a foreign language. Issues in Educational Research, 24(2), 212-227. https://www.iier.org.au

Wardhaugh, R. (1970). The contrastive analysis hypothesis. TESOL Quarterly, 4(2), 123-130. https://doi.org/10.2307/3586182

Yang, M., Cooc, N., \& Sheng, L. (2017). An investigation of cross-linguistic transfer between Chinese and English: A metaanalysis. Asian-Pacific Journal of Second and Foreign Language Education, 2(1), 1-21. https://doi.org/10.1186/s40862-017-0036-9 Yule, G. (2020). The study of language (7th ed.). https://doi.org/10.1017/9781108582889

Zhou, J., Mai, Z., \& Yip, V. (2020). Bidirectional cross-linguistic influence in object realization in Cantonese-English bilingual children. Bilingualism: Language and Cognition, 24(1), 96-110. https://doi.org/10.1017/s1366728920000231 